\title{
Freshwater microturbellarians (Platyhelminthes) from Rio Grande do Sul, Brazil
}

\author{
Jacinto Gamo ${ }^{1} \&$ Ana Maria Leal-Zanchet ${ }^{2}$ \\ ${ }^{1}$ Departamento de Biología Animal, Universidad de Alcalá. Ctra. N-II, Km 33,6, 28871 Alcalá de Henares, Madrid, Spain. \\ E-mail: jacinto.gamo@uah.es \\ 2 Instituto de Pesquisas de Planárias, Universidade do Vale do Rio dos Sinos. Avenida Unisinos 950, 93022-000 São Leopol- \\ do, Rio Grande do Sul, Brasil. E-mail: zanchet@bios.unisinos.br
}

\begin{abstract}
Ten species of freshwater microturbellarians of three ordens, Catenulida, Macrostomida and Rhabdocoela, were collected in seven sites situated in the Northeast region of Rio Grande do Sul, Brazil. Two species, Macrostomum johni Young, 1972 and Mesostoma productum (Schmidt, 1848), are cited for the first time for Brazil, the citation of $M$. johni being also the first one for the Neotropical Region. All species are cited for the first time for the state of Rio Grande do Sul.
\end{abstract}

KEY WORDS. Neotropical, new records.

RESUMO. Dez espécies de microturbelários dulciaqüícolas, pertencentes a três ordens, Catenulida, Macrostomida e Rhabdocoela, foram coletados em sete localidades situadas no Nordeste do estado do Rio Grande do Sul, Brasil. Duas dessas espécies, Macrostomum johni Young, 1972 e Mesostoma productum (Schmidt, 1848), são registradas pela primeira vez para o Brasil, sendo o registro de $M$. johni o primeiro também para a Região Neotropical. Todas as espécies são registradas pela primeira vez para o estado do Rio Grande do Sul.

PALAVRAS CHAVE. Neotropical, novos registros.

Compared to other geographical regions, the diversity and distribution of continental turbellarians from the Neotropical Region are poorly known. Besides, most of these studies focused, however, on macroturbellarians of the order Tricladida, suborders Paludicola and Terricola (see KawaKatsu et al. 1992, Seitenfus \& LEAL-ZANChEt in press). Referring to freshwater Neotropical microturbellarians, the studies are scarcer, the MARCus' studies $(1943,1944,1945 a, b, 1946,1949)$ being very important. More recently, PonCE de LeÓN $(1984,1986)$, NoREÑA-JANSSEN (1995), NoREÑAJanssen \& Faubel (1996) and Brusa et al. (2003), among others, have increased the knowledge on the diversity and distribution of this group in South-America as showed by Noreña et al. (2003).

The main purpose of the present work is to report on the results of the first survey of freshwater microturbellarians from Southern Brazil (state of Rio Grande do Sul, Brazil).

\section{MATERIAL AND METHODS}

The sample sites (Fig. 1, Tab. I) were visited once between March and April 2003. Turbellarians were collected by means of a conical hand net (mesh width $335 \mu \mathrm{m}$ ), which was used to sweep through vegetation of the margins of the water bodies. In the laboratory, samples were examined and the microturbellarians were extracted for observations in vivo by the method of progressive squash (GAMO 1987a). If necessary for species determination, part of the material was fixed with neutral formaline or Bouin (RomeIs 1989), embedded in Paraplast
(Sigma) and sectioned at $5 \mu \mathrm{m}$. Sections were stained with Mallory/Cason (RomeIs 1989).

The material was determined based on the taxonomic keys of GAMO (1987b) and Young (2001) as well as by comparison with the material described by Farías et al. (1995), Gamo \& SChwank (1987), Gamo \& Noreña-Janssen (1998), Luther (1955, 1960, 1963), Marcus (1945a, b, 1946) and NoreÑa-Janssen (1995).

\section{RESULTS AND DISCUSSION}

All species herein reported are cited for the first time for the state of Rio Grande do Sul, Brasil. Two citations, Macrostomum johni Young, 1972 and Mesostoma productum (Schmidt, 1848), are the first ones for Brazil, the citation of $M$. johni being also the first one for the Neotropical Region.

\section{Catenulida Meixner, 1924 Catenulidae Graff, 1905 Catenula lemnae Dugés, 1832}

Numerous individuals (more than 100) formed by chains of up to 20 zooids (Fig. 2) were collected in one site only (Tab. II). The species was previously recorded by MArcus (1945a) for the city of São Paulo and vicinities, state of São Paulo, and the vicinities of Curitiba, state of Paraná, Brazil, and by NoREÑAJanssen (1995) for Santa Fé, Argentina. This is the fourth record for the Neotropical Region and the third one for Brazil. 
Table I. Description and location of sampling sites in the Northeast region of Rio Grande do Sul, Brazil. ${ }^{1}$ Artificial pond, ${ }^{2}$ stream.

\begin{tabular}{|c|c|c|}
\hline Collecting site & Description & Latitude/Longitude \\
\hline São Leopoldo ${ }^{1}$ & Artificial pond (approx. $23.000 \mathrm{~m} 2$ ) in the Campus of UNISINOS & 29ㅇำ'42"S, 5109'25"W \\
\hline São Leopoldo ${ }^{2}$ & Small stream (approx. $11 \mathrm{~m}$ wide) in the Campus of UNISINOS & 2947'36"S, 51099'18" W \\
\hline \multicolumn{2}{|c|}{ Lomba Grande (Novo Hamburgo) Small lagoon (approx. 43 x 20m) in the Sinos river floodplain } & 2943'19.7"S, 5101'26"W \\
\hline Tramandaí & Small channel between two coastal lagoons $1000 \mathrm{~m}$ far from the litoral & 3000'14"S, 5009'31"W \\
\hline Nova Tramandaí & Two small coastal lagoons (approx. $30 \times 10 \mathrm{~m}$ ) 2000m far from the litora & 13001'01"S, 5009'16"W \\
\hline Nova Petrópolis & Small artificial pond (approx. $70 \times 30 \mathrm{~m}$ ) in the "Parque do Imigrante" & 2922'17" S, 510' $25^{\prime \prime} \mathrm{W}$ \\
\hline Santo Antônio da Patrulha & Small coastal lagoon $(30 \times 10 \mathrm{~m})$ partially covered by a road & 2950'32"S, 5037'53"W \\
\hline
\end{tabular}

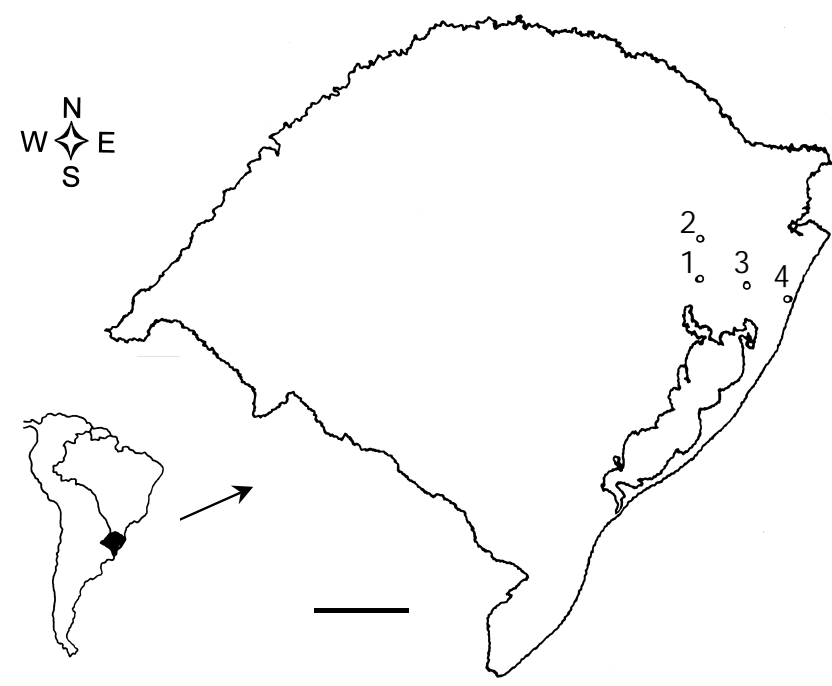

Figure 1. Location of sampling sites in the Northeast region of Rio Grande do Sul: (1) São Leopoldo and Lomba Grande, (2) Nova Petrópolis, (3) Santo Antônio da Patrulha, (4) Tramandaí and Nova Tramandaí. Bar: 100 Km.

\section{StenostomidaeVejdovsky, 1880 Stenostomm bicaudatum Kennel, 1888}

In all four collection sites (Tab. II) more than five individuals were collected. They were constituted by one or two zooids (Figs 3-4) between 1 to $2 \mathrm{~mm}$ long. All collected individuals show four spherules in the third pair of light refracting organs instead of two spherules as in the case of the specimens studied by MARCUS (1945a).

The species was previously registered by M ARCus (1945a) for the city of São Paulo, Brazil, and by NoREÑA-JANSSEN (1995) for Santa Fé, Argentina. This is the third record for the Neotropical Region and the second one for Brazil.

\section{Stenostomm grande Child, 1902}

In the three collection sites (Tab. II), where S. grande was registered, more than five individuals were collected, which are constituted al most al ways by two zooids (Fig. 5) with length between 1.7 to $2.0 \mathrm{~mm}$ long. The species was previously recorded by MARcus (1945a) for the city of São Paulo as well as for Curitiba, state of Paraná, Brazil, the present record being the third one for the Neotropical Region and Brazil.

Table II. Registered species (x) in each sampling site in the northeast region of Rio Grande do Sul, Brazil. ${ }^{1}$ Artificial pond, ${ }^{2}$ stream.

\begin{tabular}{|c|c|c|c|c|c|c|c|}
\hline Species & São Leopoldo & ${ }^{1}$ São Leopoldo ${ }^{2}$ & $\begin{array}{l}\text { Lomba } \\
\text { Grande }\end{array}$ & Tramandaí & $\begin{array}{c}\text { Nova } \\
\text { Tramandaí }\end{array}$ & $\begin{array}{c}\text { Nova } \\
\text { Petrópolis }\end{array}$ & $\begin{array}{l}\text { Santo Antônio } \\
\text { da Patrulha }\end{array}$ \\
\hline Catenula lemnae & & $x$ & & & & & \\
\hline Stenostomum bicaudatum & & $x$ & $x$ & & $x$ & & $x$ \\
\hline Stenostomum grande & $x$ & $x$ & $x$ & & & & \\
\hline Stenostomum leucops leucops & $x$ & $x$ & $x$ & & $x$ & & \\
\hline Macrostomum johni & & & & & & & $x$ \\
\hline Macrostomum tuba & $x$ & & & & & $x$ & \\
\hline Gieysztoria ornata & & & & $x$ & & & \\
\hline Gieysztoria trisolena & & & & & & & $x$ \\
\hline Mesostoma ehrenbergii & & & $x$ & & $x$ & & \\
\hline Mesostoma productum & $x$ & & & & $x$ & $x$ & \\
\hline
\end{tabular}

Revista Brasileira de Zoologia 21(4): 897-903, dezembro 2004 

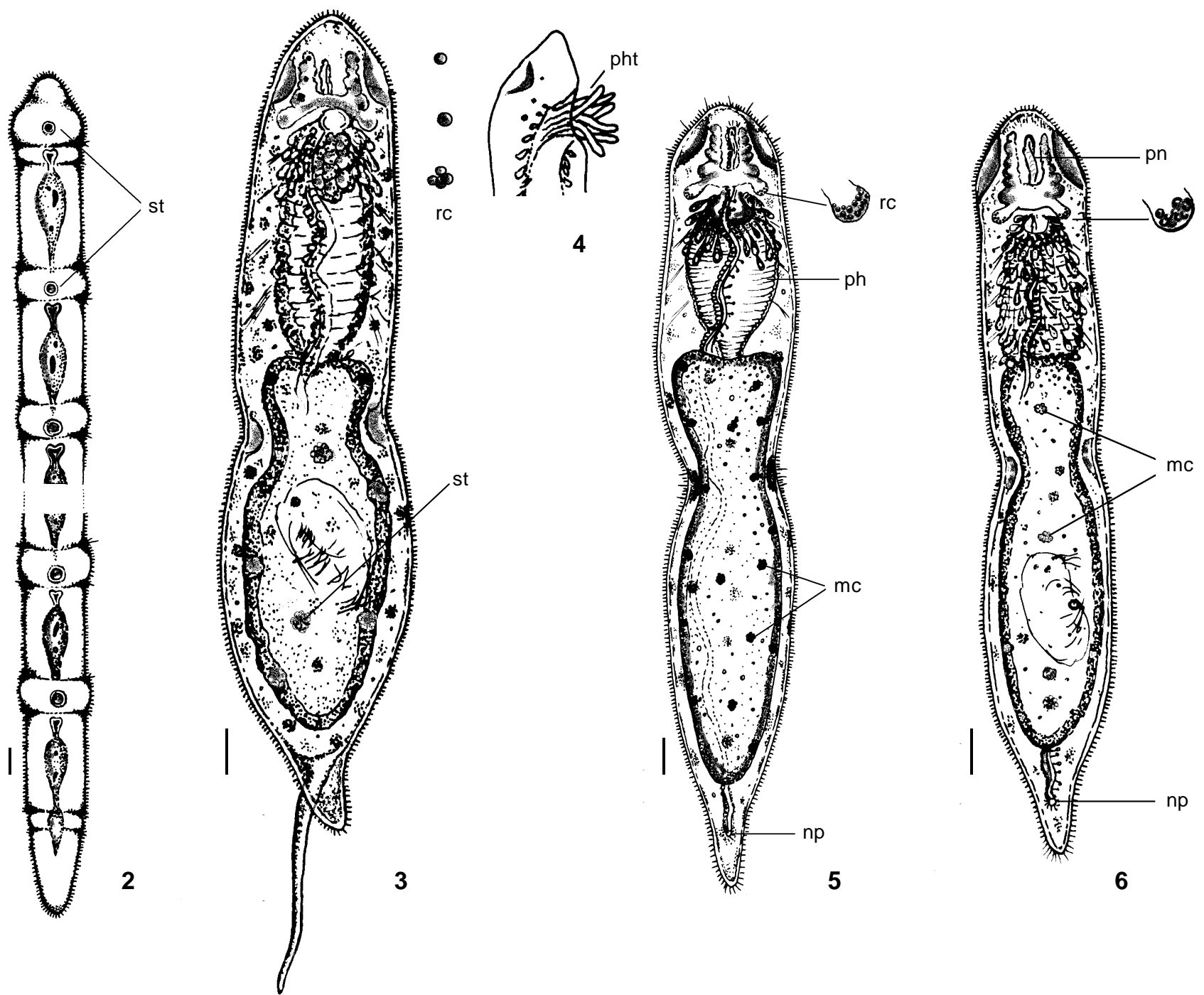

Figures 2-6. Catenulida: (2) Catenula lemnae from a small stream at UNISINOS in dorsal view; (3-4) Stenostomum bicaudatum from a lagoon at "Lomba Grande": (3) dorsal view of whole specimen; (4) cephalic region in lateral view; (5) Stenostomum grande from a lagoon at "Lomba Grande" in dorsal view; (6) Stenostomum leucops leucops from a lagoon at "Lomba Grande" in dorsal view. (mc) Minot cells, (np) nephridiopore, (ph) pharynx, (pht) pharyngeal tentacles, (pn) protonephridium, (rc) light refracting corpuscles, (st) statocyst. Bars: $100 \mu \mathrm{m}$.

\section{Stenostommleucops leucops (Dugés, 1828)}

In all four collection sites (Tab. II) more than five individuals were collected. They are constituted by two zooids (Fig. 6) with length between 1.5 and $2.0 \mathrm{~mm}$. The species was registered by MARCus (1945a), asStenostomum tenuicauda Graff, 1912, for the city of São Paulo, and as Stenostomum amphotum Marcus, 1945, for the cities of São Paulo and Campinas, state of São Paulo, both having been synonymised by LUTHER (1960) with S. leucops leucops. The present record is the fourth one for the Neotropical Region and Brazil.

\section{Macrostomida Meixner, 1924 \\ Macrostomidae Beneden, 1870 Macrostommjohni Young, 1972}

Two individuals of $M$. johni were collected in one site only (Tab. II). They are 0.6 and $0.7 \mathrm{~mm}$ long showing penis stylet with a length of 40 and $45 \mu \mathrm{m}$, respectively (Figs 7-8). In England, the individuals of $M$. johni, that have a length of up to $1.3 \mathrm{~mm}$, show a penis stylet measuring $86 \mu \mathrm{m}$ long (Young 1972). This is the first record for the Neotropical Region. 

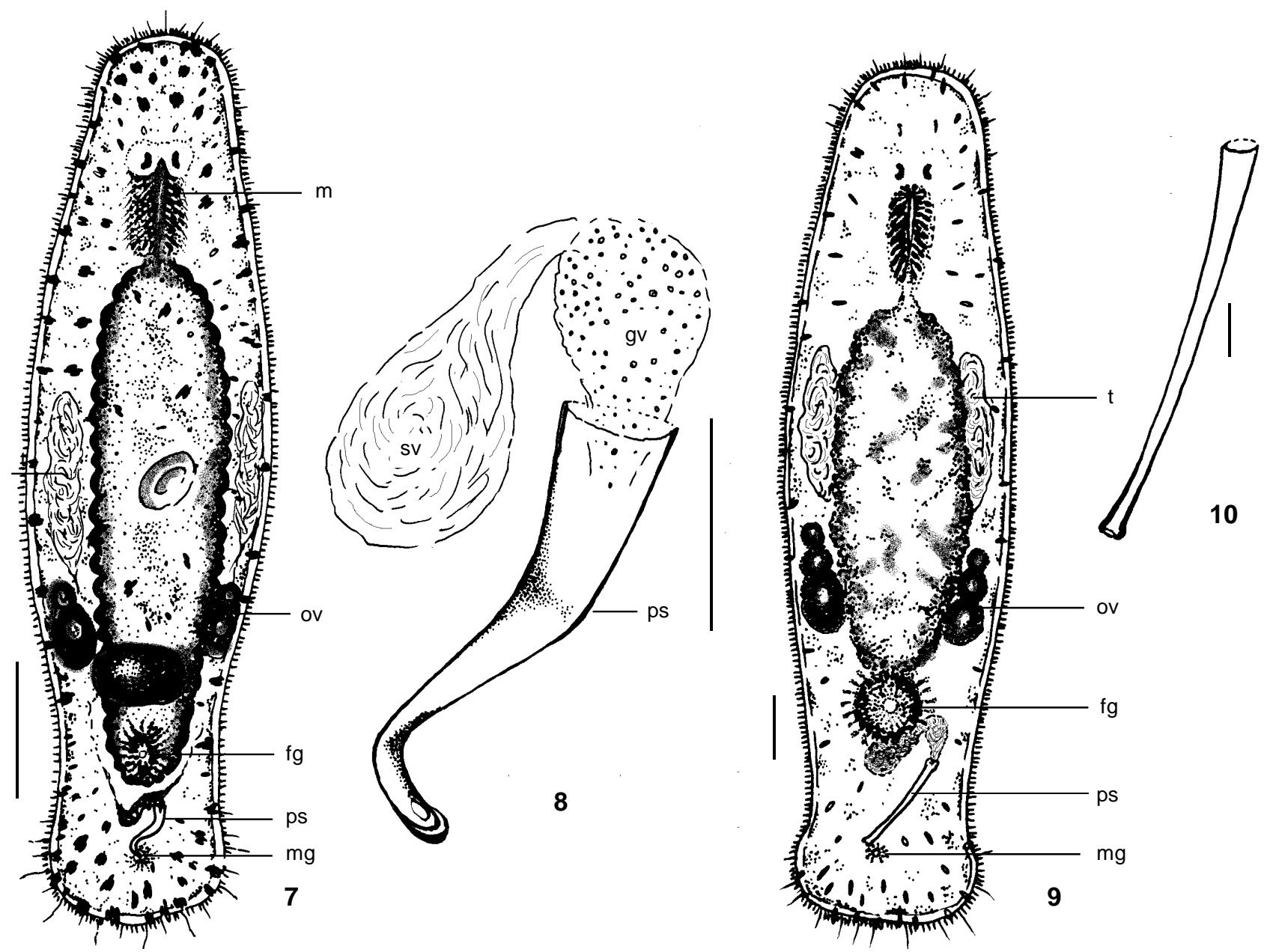

Figures 7-10. Macrostomida. (7-8) Macrostomum johni from a coastal lagoon at "Santo Antônio da Patrulha": (7) dorsal view of whole specimen; (8) detail of copulatory apparatus; (9-10) Macrostomum tuba from a pond at "Nova Petrópolis": (9) dorsal view of whole specimen; (10) detail of penis stylet. (fg) Female gonopore, (gv) granulorum vesicle, (m) mouth, (mg) male gonopore, (ov) ovary, (ps) penis stylet, (t) testes, (sv) seminal vesicle. Bars: $(7,9) 100 \mu \mathrm{m},(8,10) 20 \mu \mathrm{m}$.

\section{Macrostommtuba (Graff, 1882)}

One specimen in each collection site (Tab. II) was registered; a $1.3 \mathrm{~mm}$ long adult (Fig. 9) in Nova Petrópolis and a 0.6 $\mathrm{mm}$ long juvenilespecimen in São Leopoldo. The adult showed a penis stylet $155 \mu \mathrm{m}$ long (Fig. 10). However, the length of the stylet registered for the species varies between 280 and 420 $\mu \mathrm{m}$ (Young 2001). The species was previously registered by MARCus (1946), as Macrostomum gigas Okugawa, 1930, having been synonymised by HYMAN (1955) with M. tuba, for the city of São Paulo and vicinities, and by Hyman (1955) for Cabagua Island, near Venezuela. The present record is the third one for the Neotropical Region and the second one for Brazil.

\section{Rhabdocoela Meixner, 1925}

\section{Dalyellioida Bresslau, 1928-34}

Dalyelliidae Graff, 1903

\section{Gieystoria ornata Hofsten, 1907}

Two specimens were collected in only one collection site (Tab. II, Figs 11-12), presenting lengths of 0.5 and $0.6 \mathrm{~mm}$ with penis stylet of 25 and $30 \mu \mathrm{m}$ long, respectively, that are close to the length for the species registered by LUTHER (1955) for specimens from Brännskär and Tümpel (Northern Europe) (between 0.8 and $1.0 \mathrm{~mm}$ ), and by MARCUs (1946) for specimens from the city of São Paulo $(0.8 \mathrm{~mm})$. The present record is the second one for the Neotropical Region and Brazil. 

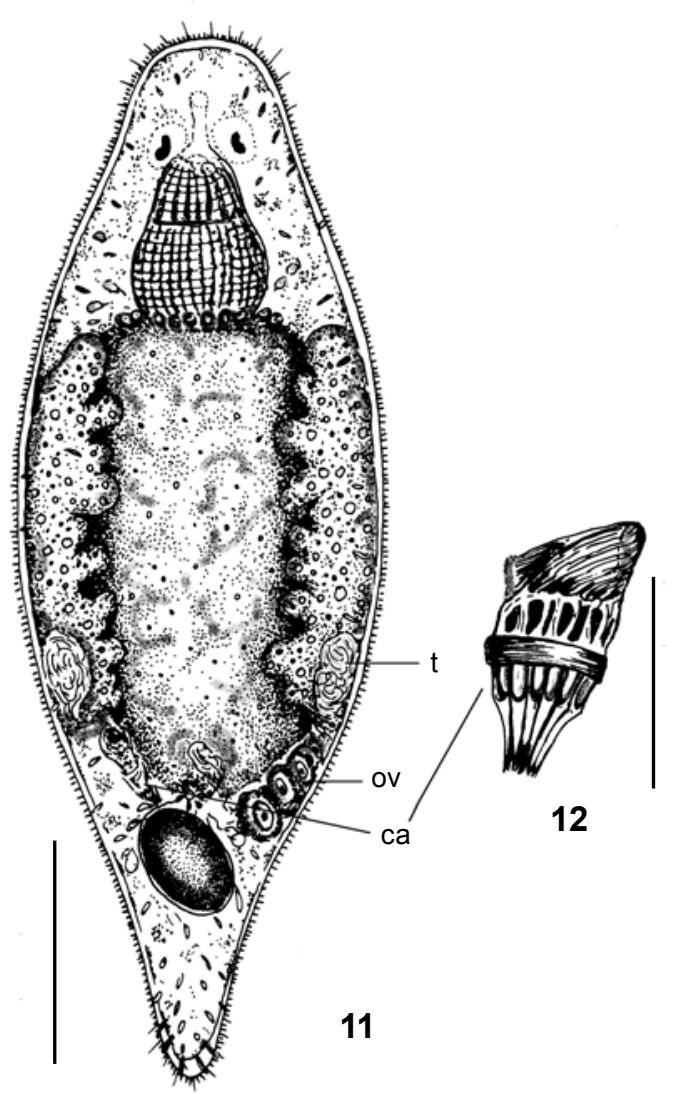

12
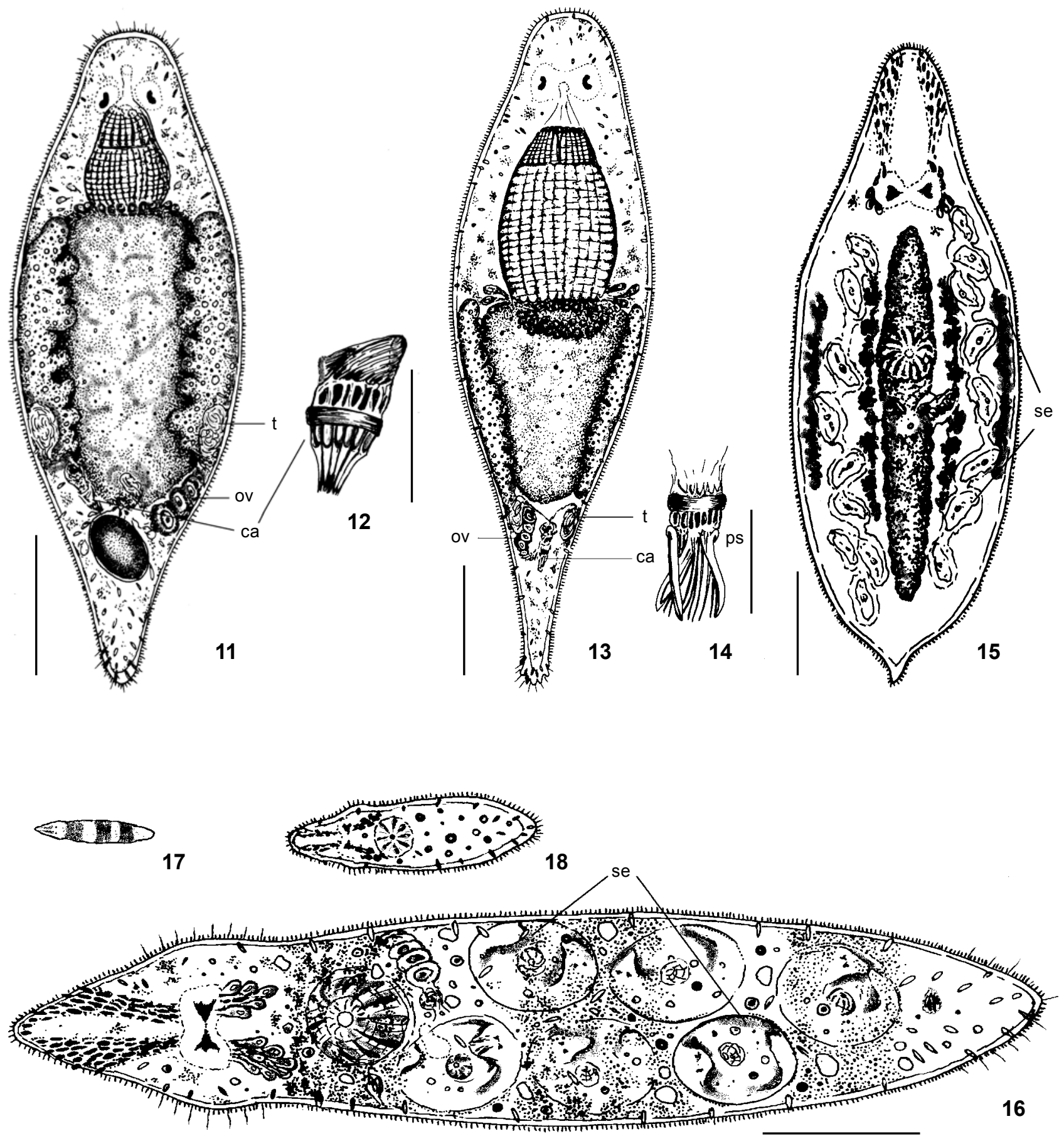

Figures 11-18. Rhabdocoela. (11-12) Gieysztoria ornata from a coastal lagoon at "Tramandaí": (11) dorsal view of whole specimen; (12) detail of copulatory apparatus; (13-14) Gieysztoria trisolena from a coastal lagoon at "Santo Antônio da Patrulha": (13) dorsal view of whole specimen; (14) detail of copulatory apparatus; (15) Mesostoma ehrenbergi from a coastal lagoon at "Nova Tramandaí" in dorsal view; (16-18) Mesostoma productum from a coastal lagoon at "Nova Tramandaí": (16) dorsal view of whole adult specimen, (17) dorsal view of external morphology of adult specimen; (18) dorsal view of whole juvenile. (ca) Copulatory apparatus, (ov) ovary, (ps) penis stylet, (se) subitaneous eggs with developing embryos, (t) testes. Bars: $(11,13,16) 100 \mu \mathrm{m},(15) 1000 \mu \mathrm{m},(12,14) 20 \mu \mathrm{m}$. 


\section{Gieystoria trisolena Marcus, 1946}

Two $0.6 \mathrm{~mm}$ long individuals were collected in only one collection site (Tab. II, Figs 13-14), which correspond very well with the description given by MARCus (1946) for the specimens from the city of São Paulo, being smaller than Marcus' specimens (up to $2.0 \mathrm{~mm}$ ). This is the second record of $\mathrm{G}$. trisolena for the Neotropical Region and Brazil.

\section{Typhloplanoida Bresslau, 1933 Typhloplanidae Graff, 1905 Mesostominae Luther, 1904}

\section{Mesostoma drenbergi (Focke, 1836)}

Two juvenile specimens were collected in Lomba Grande and an adult in Nova Tramandaí (Tab. II, Fig. 15), which are 3 $\mathrm{mm}, 4 \mathrm{~mm}$ and $6 \mathrm{~mm}$ long, respectively. Such measurements contrast with the $12-14 \mathrm{~mm}$ long adult specimens from Europe as well as with those from São Paulo ( $15 \mathrm{~mm}$ long), but are closer to the length (8-10 mm) of the specimens from Argentina (NOREÑA-JANSSEN 1995). The adult specimen showed 17 subtaneous eggs, each with a developing embryo. This worldwide distributed species was previously registered for São Paulo (Marcus 1946), Sauce, Uruguai (Ponce de León 1984), Lake Titicaca, Peru (Beauchamp 1939), Santa Fé and San Carlos de Bariloche, Argentina (NOREÑA-JANSSEN 1995), the present record being the sixth one for the Neotropical Region, the second one for Brazil.

\section{Mesostoma productum(Schmidt, 1848)}

Ten individuals were collected, two in Nova Petrópolis, three in Nova Tramandaí and five in São Leopoldo (Tab. II). They are between 0.6 and $0.8 \mathrm{~mm}$ long (Figs 16-18). The species was previously registered by NOREÑA-J ANSSEN (1995) for Santa Fé, Argentina, the description and measurements of which coincide with those of the present study. This is the second record for the Neotropical Region and the first one for Brazil.

\section{ACKNOWLEDGMENTS}

We dedicate this work to the founder of the Instituto de Pesquisas de Planárias, Prof. Dr. Josef Hauser S.J. (1920-2004), who devoted his scientific life to encourage the knowledge enhancing of morphology, taxonomy and biology of invertebrates in Rio Grande do Sul. The present study has been done during the stay of the senior author at IPP/UNISINOS, who received financial support from the Fundação de Amparo à Pesquisa do Rio Grande do Sul (FAPERGS), proc. nr. APV 02/ 16517, and whishes to thank the IPP team for its warm welcome. Thanks are also dueto thelaboratorial technicians Welcy $H$. Santos for her help with the collecting of specimens, and Letícia A. Guterres for sections preparation.

\section{REFERENCES}

Beauchamp, P. 1939. Rotifères et Turbellariés. In: The Percy Sladen Trust Expedition to Lake Titicaca in 1937 under the leadership of Mr. Cary Gilson M-A. Transactions of the Linnean Society London, London, (3) 1 (1): 51-78.

Brusa, F.; C. Damborenea \& C. Noreña. 2003. A new species of Gieysztoria (Platyhelminthes, Rhabdocoela) from Argentina and a kinship analysis of South American species of the genus. Zoologica Scripta, Göteborg, 32 (5): 449-457.

Farias, F.; J. Gamo \& C. Noreña-Janssen. 1995. Nuevas aportaciones al conocimento de los microturbelarios de la Península Ibérica. Grael Isia, Madrid, 51: 93-100.

Gamo, J. 1987a. Microturbelarios de la Península Ibérica. Miscelania Zoologica, Barcelona, 11: 41-49.

- 1987b. Claves de identificación de los turbelarios de las aguas continental es de la Península I bérica e I slas Baleares. Madrid, Asociacion Española de Limnologia, 34p.

Gamo, J. \& C. NoreÑA-JANSSEN. 1998. Old and new records of turbellarians from the central areas of Spain. Hydrobiologia, Dordrecht, 383: 299-305.

Gamo, J. \& P. Schwank. 1987. One new species of Castrada (Turbellaria, Neorhabdocoela) and four new records of microturbellarians in the Iberian peninsula. Archiv für Hydrobiologie, Stuttgart, 110 (4): 605-615.

HymAN, L. 1955. Miscellaneous marine and terrestrial flatworms from South America. American Museum Novitates, New York, 1742: 1-33.

Kawakatsu, M.; J. Hauser \& R. Ponce de León. 1992. Freshwater planarians from Uruguay and Rio Grande do Sul, Brazil: Dugesia uroriograndeana sp. nov. and Dugesia tigrina (Girard, 1850) (Turbellaria, Tricladida, Paludicola). Bulletin of the Biogeographical Society of Japan, Tokyo, 47: 1-16.

Luther, A. 1955. Die Dalyelliiden (Turbellaria Neorhabdocoela). Eine Monographie. Acta Zoologica Fennica, Helsinki, 87: 1-337.

. 1960. Die Turbellarien Ostfennoscadiens I. Acoela, Catenulida, Macrostomida, Lecithoepitheliata, Prolecithophora und Proseriata. Fauna Fennica, Helsinki, 7: 1-155.

- 1963. Die Turbellarien Ostfennoscadiens IV. Neorhabdocoela 2. Typhloplanoida: Typhloplanidae, Solenopharyngidae und Carcharodopharyngidae. Fauna Fennica, Helsinki, 16: 1-163.

MARCUS, E. 1943. O Turbelário Mesostoma ehrenbergii (Focke, 1836) no Brasil. Boletim da Indústria Animal, São Paulo, 6 (1-2): 12-15.

- 1944. Sobre duas Prorhynchidae (Turbellaria), novas para o Brasil. Arquivos do Museo Paranaense, Curitiba, 4: 3-46.

. 1945a. Sobre microturbelários do Brasil. Comunicaciones de Zoologia del Museo de Historia Natural de Montevideo, Montevideo, 25: 1-74.

. 1945b. Sobre Catenulida Brasileiros. Boletim da Fa-

Revista Brasileira de Zoologia 21(4): 897-903, dezembro 2004 
culdade de Filosofia, Ciências e Letras da Universidade de São Paulo, série Zoologia, São Paulo, 10: 3-133. . 1946. Sobre Turbellaria Brasileiros. Boletim da Faculdade de Filosofia, Ciências e Letras da Universidade de São Paulo, série Zoologia, São Paulo, 11: 5-254. . 1949. Turbellaria Brasileiros (7). Boletim da Faculdade de Filosofia, Ciências e Letras da Universidade de São Paulo, série Zoologia, São Paulo, 14: 7-156.

NoreÑA-JANSSEN, C. 1995. Studies on the taxonomy and ecology of the turbellarian (Plathelminthes) in the floodplain of the Paraná river (Argentina). II. Taxonomy and ecology of the Turbellaria. Archiv für Hydrobiologie, Stuttgart, Suppl. 107: 11-262.

Noreña-JansSen, C. \& A. Faubel. 1996. Myoretronectes paranaensis n.gen et sp., a new freshwater genus of the family Retronectidae (Turbellaria, Catenulida) from the Paraná, Argentina. Hydrobiologia, Dordrecht, 330: 111-118.

Noreña, C.; F. Brusa \& A. Faubel. 2003. Census of "Microturbellarians" (free-living Platyhelminthes) of the zoogeographical regions originating from Gondwana. Zootaxa, Auckland, 146: 1-34.

Received in 22.III.2004; accepted in 11.XI.2004.
Ponce de León, R. 1984. Turbellaria del Uruguay II. Sobre Mesostoma ehrenbergii (Foche) (Rhabdocoela Typhloplanidae). Revista dela Facultad deHumanidades y Ciencias, Serie Ciencias Biológicas, La Plata, 1: 381-391.

Ponce de León, R. 1986. Turbellaria del Uruguay III. Sobre Bothromesostoma evelinae Marcus, 1946 (Rhabdocoela, Typhloplanidae). Comunicaciones Zoológicas del Museo de Historia Natural de Montevideo, Montevideo, 11: 1-17.

Romels, B. 1989. Mikroskopische Technik. München, Urban und Schwarzenberg, 697p.

Seitenfus, A.L.R. \& A.M. LeAl-Zanchet. (in press). Uma introdução à morfologia e taxonomia de planárias terrestres (Platyhelminthes, Tricladida, Terricola). Acta Biologica Leopoldensia, São Leopoldo, 26 (2).

YounG, J.O. 1972. Further studies on the occurrence of freshwater Microturbellaria in the British Isles. 1. A description of Macrostomum johni sp. nov. Freshwater Biology, Oxford, 2: 253-258.

Young, J. O. 2001. Keys to the fresh water microturbellarians of Britain and Ireland with notes on their ecology. Ambleside, The Freshwater Biological Association, 142p. 